\title{
Islamic Mutual Funds Promotional Activities: Normal Approximation of Binomial Distribution and Type I Error
}

\author{
Mohd Yaziz Bin Mohd Isa ${ }^{1}$, Hannan Azzahra ${ }^{2}$, Zulkifflee Mohamed ${ }^{3}$
}

\begin{abstract}
The paper applies the normal approximation procedure to a binomial probability distribution. A sample of 392 respondents is surveyed whether they agree or not agree that promotional activities determined the level of awareness of the benefits of Islamic mutual funds. The paper hypothesizes the population mean $\mu$ of success effects of promotional activities at 68\%, and attempts to reduce Type I error - the probability of rejecting the null hypothesis when it is true. This study reveals that $0.68 \%$ of respondents agreed that promotional activities determined the level of awareness of the benefits of Islamic mutual funds.
\end{abstract}

Keywords: Binomial probability distribution, normal probability distribution, Islamic mutual funds

\begin{abstract}
Abstrak. Studi ini menerapkan prosedur perkiraan normal untuk distribusi probabilitas binomial. Survey dilakukan terhadap sampel yang terdiri dari 392 responden untuk mengetahui apakah mereka setuju atau tidak setuju bahwa kegiatan promosi menentukan tingkat kesadaran akan manfaat reksa dana syariah. Hipotesis yang diuji adalah rata-rata populasi $\mu$ keberhasilan kegiatan promosi sebnyak 68\% dan berupaya untuk mengurangi kesalahan Tipe 1-kemungkinan untuk menolak hipotesis null. Studi ini menemukan bahwa $0.68 \%$ dari responded menyetujui bahwa aktifitas promosi menentukan tingkat kesadaran akan manfaat reksadana.
\end{abstract}

Kata kunci: Binomial probability distribution, normal probability distribution, Islamic mutual funds 


\section{Introduction}

This paper attempts to estimate a normal probability distribution, which is a continuous probability distribution as a substitute to a binomial probability distribution of promotional activities of Islamic mutual funds. The binomial probability distribution, on the other hand, is a discrete probability distribution. The paper also discusses the risk of committing Type I error, i.e. probability of rejecting the null hypothesis when it is true.

The responses from an opinion polling of effects of promotional activities of Islamic mutual funds are in the form of a binomial probability distribution. The respondents were asked, "do you agree that promotional activities determined the level of awareness of the benefits of Islamic mutual funds?". One obvious reason to substitute using the normal probability for approximating the binomial distribution is for large values of $n$ (i.e. sample size) a binomial distribution becomes closer and closer to a normal distribution (Lind, Marchal and Wathen, 2015). The opinion polling where the normal approximation applied to approximate the binomial distribution is such an example. Another reason is the estimation procedure becomes more efficient through the use of normal probability approximation for the binomial distribution for a survey with a large value of $n$. By extension, the reason to determine the risk of committing Type I error in the estimation procedure is to control Type I error. Ramsey and Ramsey (1988) advocate the view that normal approximation as robust for a given sample size $n$ and at a given level of $\alpha$ (the risk of Type I error) if the error never exceeds $1.5 \alpha$.

In this paper, the binomial parameter to denote "success" of an outcome is when respondents respond as "agree" that promotional activities determined the level of awareness of the benefits of Islamic mutual funds. The calculated "success" is $68 \%$. This percentage is arrived at because, from the survey, 267 respondents of a total of 392 respondents responded "agree" promotional activities determined the level of awareness of benefits of Islamic mutual funds.

As in any binomial distribution, there can be only two mutually exclusive possible outcomes (events or replies) in the opinion polling. The possible outcomes are either "success" or "failure". Henceforth, the "failure" outcome is when the respondent does not agree (that promotional activity determined the level of awareness of the benefits of Islamic mutual funds). Since the "success" outcome is $68 \%$ (or 0.68$)$, the "failure" outcome is $32 \%(1-0.68=0.32)$. As stated earlier, a condition for the binomial experiment is that respondent can choose only one of two possible responses either "agree" or "does not agree"; but the respondent cannot choose both responses at the same time.

Generating a binomial probability distribution for a large number of respondents, for example, for 300 respondents in this paper would become more 
efficient using normal probability distribution. Because when the sample size is large and exceeding $n=30$, binomial distribution automatically approaches a normal distribution.

\section{Literature Review}

The size of the Islamic capital market in Malaysia stands at RM1,961.73 billion (Securities Commission Malaysia, 2018) as of $31^{\text {st }}$ August 2018. It constitutes about $60.33 \%$ of the total market share of capital market of RM3,251.67 billion.

Of the total asset of RM790.80 billion (@ 31 $1^{\text {st }}$ August 2018), RM171.53 billion (or 21.69\%) comprises of Islamic assets (Securities Commission Malaysia, 2018). The composition of Islamic assets of $21.69 \%$ as at $31^{\text {st }}$ August 2018 is increasing over the years from 19.82\% (@ December 2015) to 21.49\% (@ December 2016) and then to 22.01\% (@ December 2017).

An Islamic mutual fund is a form of collective investment that allows investors to pool their funds to invest by fund professionals in a portfolio of assets or securities that are Sharia-compliant. Some examples of the assets or securities that are Shariacompliant are Islamic-counters securities, sukuk, Islamic unit trusts, Sharia indices, warrants, call warrants, and crude palm oil futures contract. The Sharia compliance matter is what makes the Islamic mutual funds differ from that of their conventional counterparts.

The increase in the number of Sharia-compliant funds available in the market and the growing units purchase over the years demonstrates the great potential of both the demand and the supply of the funds. But the present market conditions post imminent challenges. The number of investors is increasing at a declining rate, and it gives rise to a question "why do they prefer to invest in conventional mutual funds?" There is also a lack of awareness among investors and their understanding of the roles of fund professionals and an understanding of what differentiate Islamic mutual funds from that of their conventional counterparts. A lack of variety in product offerings, according to Yusuff and Mansor, 2014, is another contributing factor. As a result, creating awareness among investors at the basic level is an increasingly important area in promoting and marketing of Islamic mutual funds.

Brand awareness is defined as the level of involvement, which begins with brand name recognition. The lowest level of brand awareness recognizes the brand name, while the highest level is the ability to develop detailed information about the products and services offered based on the brand name. Many studies show the consumers' behaviours are influenced by awareness and knowledge about the products and services offered. (Chartrand, 2005; Coulter et al. 2005; Dommeyer \& 
Gross, 2003; Donoghue \& De Klerk, 2009; Hartlieb \& Jones, 2009; McEachern \& Warnaby, 2008; and Thomas \& Mills, 2006).

The use of standard normal probability distribution to approximate binomial probability distribution when there is a large value of " $n$ " (i.e. $n$ is a sample size) is an alternative or an option. It is so because as " $n$ " increases, a binomial probability distribution becomes closer and closer to resemble a standard normal probability distribution.

Returning to the criteria for the binomial probability distribution, they are:

i. There are only two mutually exclusive outcomes or outputs either "agree" or "does not agree" to an opinion polling or question "promotional activities determined the level of awareness of benefits of Islamic mutual funds?".

ii. The probability of "success" in each experiment or survey remains the same from one respondent to another. This probability is calculated from the opinion polling or survey response, where $68 \%$ (i.e. 267 of 392 respondents) indicate they "agree" that promotional activities determined the level of awareness of benefits of Islamic mutual funds. In other words, the level of awareness of the benefits of Islamic mutual funds is determined by promotional activities as the likely response from each respondent remains the same at 0.68. So, $\pi=0.68$.

iii. The "trials" or responses are independent of each other, meaning - for example, if the $10^{\text {th }}$ respondent agrees, it does not affect whether the $11^{\text {th }}$ respondent agrees. Likewise, if the $10^{\text {th }}$ respondent does not agree, it does not affect whether the $11^{\text {th }}$ respondent does not agree.

iv. $\mathrm{n} \pi$ and $\mathrm{n}(1-\pi)$ are both at least five according to Lind, Marchal and Wathen, 2015. In this paper $n \pi=392(0.68)=266.56$ therefore $n \pi \geq 5$, and $n(1-\pi)=$ $392(0.32)=125.44$ therefore $\mathrm{n}(1-\pi) \geq 5$.

\section{Methodology}

The paper attempts to find from a random sample "at least 300 respondents" agree promotional activities determined the level of awareness of benefits of Islamic mutual funds. At a chosen level of significance at $1 \%$, the hypothesis is set as below. We hypothesize the population mean $\mu$ of success effects of promotional activities is $68 \%$ (based on 267 of 392 respondents surveyed who indicated they "agree");

$\mathrm{H}_{0}: \quad \mu \leq 0.68 \%$ of respondents agree the promotional activities did not determine the level of awareness of benefits of Islamic mutual funds (the hypothesis tested).

$\mathrm{H}_{0}: \quad \mu>0.68 \%$ of respondents agree the promotional activities determined the level of awareness of benefits of Islamic mutual funds (the research hypothesis).

In the procedure where normal approximation substitutes for the binomial probability distribution, a value of 0.5 , termed as "continuity correction factor" is 
applied. In short, it is applied in the estimation procedure to find the probability " $a t$ least 300 respondents" agree promotional activities determined the level of awareness of benefits of Islamic mutual funds. In order to apply the "continuity correction factor" to the value of "at least 300 respondents," the estimation procedure begins from 299.5 (i.e. $300-0.5=299.5$ ).

The binomial distribution is given by the formula:

$$
\begin{aligned}
& \mathrm{P}(\mathrm{x} ; \mathrm{n}, \pi)=\sum_{x=0}^{n}\left(\begin{array}{l}
n \\
x
\end{array}\right) \pi^{x} q^{n-x} \quad \text { for } \mathrm{x}=1,2,3 \ldots \mathrm{n} \text {. } \\
& \mathrm{P}(\mathrm{X} \geq 300 ; 392,0.68)=\sum_{x=300}^{n=392}\left(\begin{array}{c}
392 \\
300
\end{array}\right) \pi=0.68^{300} q=0.32^{392-300=92} \text { for } \mathrm{x}=300,301, \ldots .392 . \\
& \mathrm{P}(\mathrm{X}=\mathrm{x})={ }_{\mathrm{n}} \mathrm{C}_{\mathrm{x}}(\pi)^{\mathrm{n}}(1-\pi)^{\mathrm{n}-\mathrm{x}} \\
& =\frac{\mathrm{n} !}{\mathrm{x} !(\mathrm{n}-\mathrm{x}) !(\pi)^{\mathrm{x}}(1-\pi)^{\mathrm{n}-\mathrm{x}}}
\end{aligned}
$$

\section{Results \& Discussions}

Now returning to the purpose of the paper, to find the probability randomly selected respondents from the 392 total respondents "at least 300 respondents" agree promotional activities determined the level of awareness of benefits of Islamic mutual funds, the construction of the binomial probability methodology is as follows:

\section{Binomial probability construction}

The binomial distribution is calculated as follows;

Firstly, $\mathrm{P}(\mathrm{x}=300)={ }_{392} \mathrm{C}_{300}(\pi)^{300}(1-\pi)^{392-300}$

$$
\begin{aligned}
& ={ }_{392} \mathrm{C}_{300}(0.68)^{300}(1-0.68)^{392-300} \\
& =0.000046391
\end{aligned}
$$

We continue further with $\mathrm{x}=301$.

$$
\begin{aligned}
\mathrm{P}(\mathrm{x}=301) & ={ }_{392} \mathrm{C}_{301}(\pi)^{301}(1-\pi)^{392-301} \\
& =0.000030131
\end{aligned}
$$

And, further with $\mathrm{x}=302$, and so forth.

$$
\begin{aligned}
& \mathrm{P}(\mathrm{x}=302)={ }_{392} \mathrm{C}_{302}(\pi)^{302}(1-\pi)^{392-302}=0.000019293 \\
& \mathrm{P}(\mathrm{x}=303)={ }_{392} \mathrm{C}_{303}(\pi)^{303}(1-\pi)^{392-303}=0.000012178 \\
& \mathrm{P}(\mathrm{x}=304)={ }_{392} \mathrm{C}_{304}(\pi)^{304}(1-\pi)^{392-304}=0.000007576 \\
& \mathrm{P}(\mathrm{x}=305)={ }_{392} \mathrm{C}_{305}(\pi)^{305}(1-\pi)^{392-305}=0.000004645
\end{aligned}
$$

In summary, the procedure continues further with $\mathrm{x}=306$ and so forth for all the 392 respondents until last where $\mathrm{x}=392$ to find the probability "at least 300 respondents" agree promotional activities determined the level of awareness of benefits of Islamic mutual funds. 
We then sum of the total probabilities for all values of $\mathrm{x}$ from the first respondent $\left(300^{\text {th }}\right)$ to the last $\left(392^{\text {nd }}\right)$. However, the calculation procedure by this method would be tedious, time-consuming and impractical. Using this method, we measure the probability for 93 times (one time for each value of $\mathrm{x}$ from $\mathrm{x}=300$ to $\mathrm{x}=392$ inclusive). In real applications, the binomial tables may not be available because the number of trials (300) is so large.

\section{Normal approximation to Binomial probability distribution}

Returning to the purpose of the paper to substitute using normal approximation to binomial probability distribution to determine the probability "at least 300 respondents" agree that promotional activities determined the level of awareness of the benefits of Islamic mutual funds, we use the area below $\mathrm{x}=300-0.5$ (i.e. $x=299.5$ after subtracting 0.5 from 300). Therefore, $x=299.5$.

To find the $\mathrm{Z}$-value corresponding to $\mathrm{x}=299.5$ with the $\mu$ for a binomial probability distribution which is $\mu=\mathrm{n} \pi=392(0.68)=266.56$, and the variance $\mathrm{n} \pi$ $(1-\pi)=392(0.68)(1-0.68)=85.2992$, and standard deviation $=9.2357$

$\mathrm{P}(299.5 \leq \mathrm{X} \leq 392.5)=\mathrm{Z}$-value $=\underline{\overline{\mathrm{x}}-\mu}$

Std. deviation

$$
=\frac{299.5-266.56}{9.2357}=3.566
$$

Under the normal curve with a $\mathrm{Z}$-value $=3.566$ lies within rejection region (beyond 2.33), $\mathrm{H}_{0}$ is rejected. It implies the probability of obtaining such an extreme estimate of 2.33 standard deviation above from the $\mu$ is less than $1 \%$ (the chosen level of significance). Therefore, it can be concluded that $0.68 \%$ of respondents agree the promotional activities determined the level of awareness of the benefits of Islamic mutual funds.

Graph 1: Normal curve with $1 \%$ level of significance

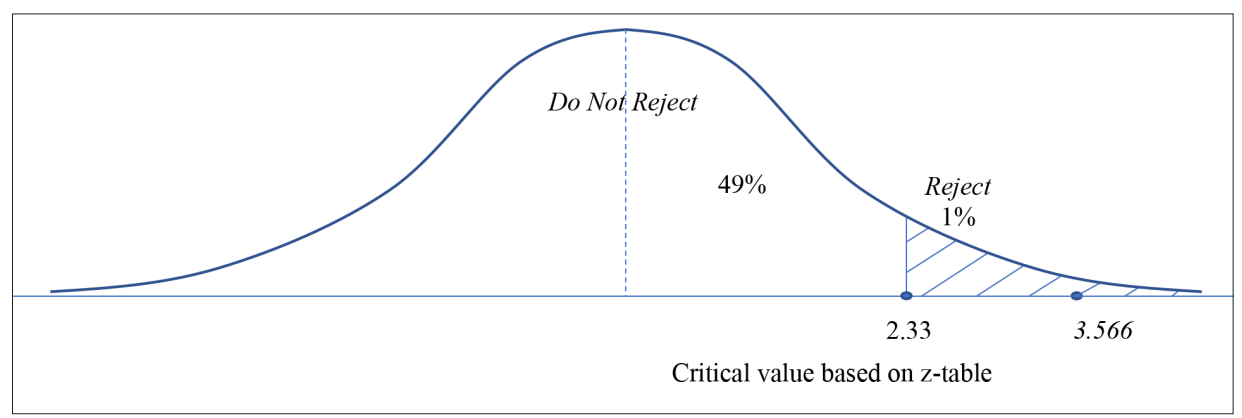




\section{TYPE I error}

Type I error is the probability of rejecting the null hypothesis when it is true. In the above calculations, suppose that the null hypothesis is true, there is a $1 \%$ chance that $\mu$ is larger than 2.33 that we decide to reject the null hypothesis. In short, there is a $1 \%$ chance of committing a type I error.

We can reduce the risk of committing type I error by reducing the size of the rejection region. We could lower (revise) the level of significance from $1 \%$ (as in graph 1 above) to $0.02 \%$ (as in graph 2 below). With the lower level of significance at $0.02 \%$, it implies that the probability of getting the sample value is now $0.02 \%$. Now our chance to make type I error is $0.02 \%$ of the time.

Graph 2: Normal curve with $0.02 \%$ level of significance

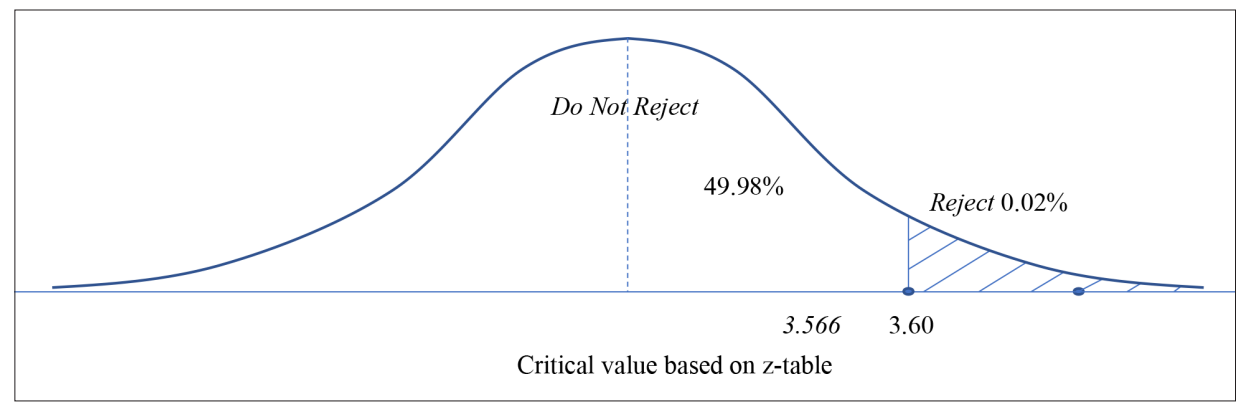

With the lower level of significance of $0.02 \%$, under the normal curve with a $\mathrm{Z}$-value $=3.566$ lies within the non-rejection region (below 3.60), $\mathrm{H}_{0}$ is not rejected.

\section{Conclusions}

In conclusion, $0.68 \%$ of respondents agreed that promotional activities determined the level of awareness of the benefits of Islamic mutual funds. As such, the null hypothesis that $\mathrm{H}_{0:} \mu \leq 0.68 \%$ was rejected at $1 \%$ level of significance. At the lower level of significance of $0.02 \%$ however, $\mathrm{H}_{0}$ was not rejected. Future study may explore the relationship on the level of consumer awareness with purchase intentions of Islamic mutual funds.

\section{References}

Biswal, Purna Chandra. 2009. Probability and Statistics. New Delhi: PHI Learning Private Limited. 
Brown, Lawrence D., Cai, T. Tony \& DasGupta, Anirban. 2001. "Interval Estimation for Binomial Proportion." Statistical Science 16(2): 101-133.

Chartrand, Tanya. L. 2005. "The Role of Conscious Awareness in Consumer Behavior." Journal of Consumer Psychology 15(3): 203-210.

Coulter, Robin. A., Linda L. Price, Lawrence Feick \& Camelia Micu. 2005. "The Evolution of Consumer Knowledge and Sources of Information: Hungary in Transition." Journal of the Academy of Marketing Science 33(4): 604-619.

Dommeyer, Curt J., \& Barbara L. Gross. 2003. "What Consumers Know and What They Do: An Investigation of Consumer Knowledge, Awareness, and Use of Privacy Protection Strategies." Journal of Interactive Marketing 17(2): 34-51.

Donoghue, Sune \& Helena M. De Klerk. 2009. "The Right to Be Heard and to Be Understood: A Conceptual Framework for Consumer Protection in Emerging Economies." International Journal of Consumer Studies 33(4): 456-467.

Hartlieb, Susanne \& Bryn Jones. 2009. "Humanising Business through Ethical Labelling: Progress and Paradoxes in the UK." Journal of Business Ethics 88(3): 583-600.

Lind, Douglas A., William G. MArchal \& Samuel A. Wathen. 2015. Statistical Techniques in Business \& Economics. 16 ${ }^{\text {th }}$ ed. New York: McGraw Hill Education.

McEachern, Morven G. \& Gary Warnaby. 2008. "Exploring the Relationship between Consumer Knowledge and Purchase Behaviour of Value-based Labels." International Journal of Consumer Studies 32(5): 414-426.

Ramsey, Phillip H. \& Patricia P. Ramsey. 1988, "Evaluating the Normal Approximation to the Binomial Test." Journal of Educational and Behavioral Statistics 13(2): 173-182.

Selvanathan, Anthony, Saroja Selvanathan, Gerald Keller \& Brian Warrack. 2000. Australian Business Statistics. South Melbourne, Victoria: Nelson Thomson Learning.

Thomas Jr., Lionel., \& Juline E. Mills. 2006. "Consumer Knowledge and Expectations of Restaurant Menus and Their Governing Legislation: A Qualitative Assessment." Journal of Foodservice 17(1): 6-22.

Triola, Mario F. 2017, Elementary Statistics. $13^{\text {th }}$ ed. Boston: Pearson Addison Wesley. Yusuff, Noraini \& Mansor Fadillah. 2014. "Proposed Model for the Factors Influencing Muslim Investors in Choosing Islamic Unit Trust Funds. ”ournal of Global Business and Social Entrepreneurship (GBSE) 1(2): 113-120. 


\title{
Public Willingness to Pay for Halal Certified Beef
}

\author{
Muhammad Dzakir Fiqi ${ }^{1}$, Darwanto ${ }^{2}$
}

\begin{abstract}
This research aims at analyzing the scale of public willingness to pay for halal-certified beef and the influence of age, income, awareness, perception, and religiosity on their willingness. This study employs a purposive sampling method to obtain 100 respondents. Descriptive statistical analysis is used along with contingent valuated method and logit regression. The result shows that 77 of the respondents are willing to pay more for halal-certified beef, while the other 23 are not. The average value of WTP obtained is $7 \%$ of the ordinary meat price. The result of logit regression analysis shows that awareness variable has a significant effect on willingness to pay halal certified beef, while the income, age, perception, and religiosity do not have a significant effect.
\end{abstract}

Keywords: Halal Certificate, Willingness to Pay, Consumer Behaviour, Contingent Valuated Method, Logit Regression

\begin{abstract}
Abstrak. Penelitian ini bertujuan untuk menganalisis besaran kesediaan membayar masyarakat serta menganalisis pengaruh usia, pendapatan, awareness, persepsi dan religiusitas terhadap kesediaannya membayar daging sapi bersertifikat halal. Penelitian ini dilakukan di Provinsi DKI Jakarta dengan metode purposive sampling dan responden yang berjumlah 100. Metode analisis yang digunakan dalam penelitian ini adalah analisis statistik deskriptif, contingent valuated method, dan regresi logit. Hasil yang diperoleh menjukkan bahwa 77 responden bersedia membayar lebih daging sapi bersertifikat halal, sementara 23 lainnya tidak. Rataan nilai WTP yang diperoleh adalah $7 \%$ dari harga daging sapi biasa. Hasil dari analisis regresi logit menunjukkan bahwa variabel awareness berpengaruh signifikan terhadap kesediaan membayar daging sapi bersertifikat halal. Sementara usia, pendapatan, persepsi, dan religiusitas tidak berpengaruh signifikan.
\end{abstract}

Kata kunci: Sertifikat halal, Kesediaan untuk membayar, Perilaku konsumen, Contingent Valuated Methode, Regresi Logit

\footnotetext{
${ }^{1,2}$ Faculty of Economics and Business, Universitas Diponegoro

E-mail: dzakirfiqi@gmail.com
} 


\section{Introduction}

Consuming halal products is an obligation for Muslims and part of the worship of Allah. Disobeying this obligation is a serious violation against Islamic teaching. Besides, Muslims are suggested to consume good (toyyib) food. Tayyib or tayyiban can be translated as complement and perfectness of halal food in the forms of cleanliness, safety, health, usefulness and other aspects that are in accordance with conditions and needs (Kamaruddin et al. 2013).

Halal literally means "allowed"; in general; it can be translated into something that is allowed based on Islamic laws. Halal products are one of the crucial instruments for Muslims in performing various activities, including consumption. This is the order of Allah that has been stated in the Quran, Sura Al Baqara verse 168.

Basically, halal is a process of trust of the attribute that cannot be seen and cannot be confirmed, so it is difficult to be evaluated by individual consumers (Verbeke et al., 2013). For example, consumers buy meat at the seller who they think credible enough. This makes them trust the halal status of the meat and buy it from the seller. However, because the trust is implicit, it raises trust abuse cases (Zakaria, 2008).

In this case, abusing the trust is in the form of the discrepancy between the expected product with the real one. For example, the expected halal meat is mixed with the non-halal one. An instance for this type of case is the foreclosure of $178.5 \mathrm{~kg}$ of beef spindles in Ponorogo Regency (www.kompas.com accessed on 20 $0^{\text {th }}$ August 2017).

The selling of meat without halal guarantee has been a problem for Indonesian Muslim people considering that meat is one of the most consumed food. According to the data from the Central Bureau of Statistics, there had been an increasing trend of meat consumption per capita from 2007-2015.

Figure 1. Average of Consumption per Capita of Meat Product in a week in Indonesia in 2007-2015

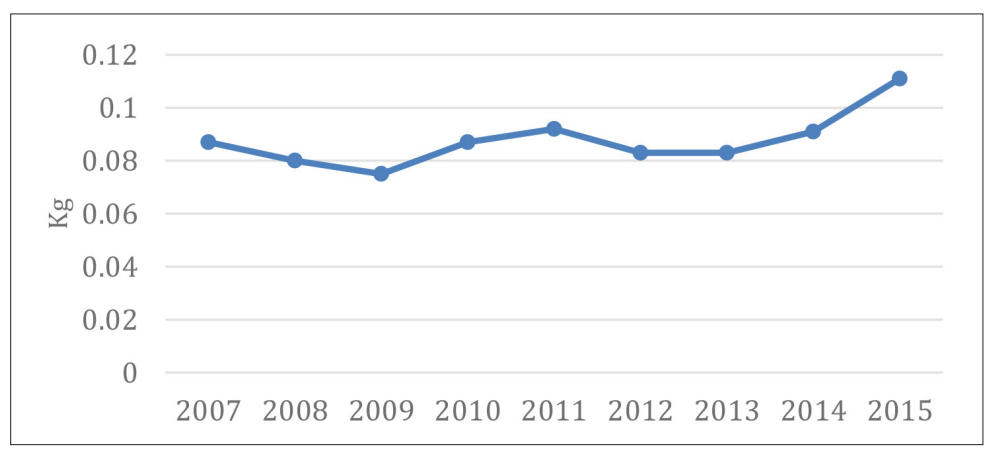

Source: Central Bureau of Statistics, processed in 2017. 
The issue of cross-contamination between the halal and haram products also increases the consumers' risk in consuming the meat that is not in accordance with their preference (Verbeke, 20015). Such condition makes the consumers search for a guarantee to ensure that the product they buy is halal, and the certification of halal meat is an answer to provide guarantee and certainty of the meat that the consumers buy (Verbeke et al., 2013).

However, the improvement and implementation of halal certification on the chain of halal meat may increase the price of the meat (Angulo and Gil 2007). This is because of the additional costs in processing and handling the meat to be in accordance with Islamic law. Therefore, it is crucial to find out the consumers' willingness to pay for the halal-certified meat in order to describe the consumers' demand on the product.

This research refers to the previous study by Ibrahim (2011). This particular study aims at analyzing the willingness to pay (WTP) of Muslims in Georgia in buying premium qualified halal lamb. Verbeke et al. (2013) researched to find out the value of willingness to pay of the Muslims in Belgium in buying the halalcertified chicken in supermarkets and Islamic butcher shops. The research of Bonne et al. (2008) aims at finding out the factors affecting the halal meat consumption of the Muslims in Belgium using the planned behavior theory.

A research on the consumers' willingness to pay for halal-certified beef has not yet been done. This particular study aims at finding out the scale of consumer's WTP on halal certified beef and analyzing whether ages, income, awareness, perception, and religiosity affect the WTP for halal-certified beef.

\section{Literature Review}

Kamaruddin, Ibrahim and Shabudin (2013) conducted research entitled "Factors Influencing Customers' Willingness to Pay for Halal Logistics". This research was conducted to 221 respondents spread over Selangor, Klang Valley, and Marang, Terengganu. The analysis instrument used is the logit model. The research reveals that the variables of parents' status and perception of halal logistics have a negative connection with the WTP for halal logistics, whereas the consumers' WTP for halal logistics has a positive connection with the demand and procurement cost of halal logistics.

Research by Verbeke et al. (2013), entitled "Credence Quality Coordination and Consumers' Willingness to Pay for Certified Halal Labelled Meat", was conducted to 202 Muslim respondents. This research is analyzed using the double hurdle model regression. The result concludes that Muslim consumers have been 
willing to pay for the chicken meat with a higher price sold by the Muslim sellers rather than those sold in the supermarket. The female consumers pay more attention to the halal status of the meat compared to male consumers.

Bonne, Vermeir and Verbeke (2009) conducted research entitled "Impact of Religion on Halal Meat Consumption Decision Making in Belgium". The data was collected from 367 respondents of Muslim migrants living in Belgium. The research reveals that healthy behavior affects the intention to consume halal meat. The Muslims with high religiosity intend to consume the halal meat because they believe that the meat is healthy, whereas the Muslims with low religiosity intend to consume the halal meat because of the influence of their relatives from the same religion and because of their healthy behavior.

Research by Ibrahim (2011), entitled “Consumers' Willingness to Pay a Premium Halal Goat Meat: A Case from Atlanta, Georgia”, was conducted to 89 respondents and used the probit model. The average of WTP for halal-certified mutton is 50 cents per pound of meat. The variables of income and amount of family members significantly affect the WTP for halal mutton on $1 \%$ degree.

Research by Bonne, Vermeir and Blackler (2007), entitled "Determinants of Halal Meat Consumption in France", was conducted by a survey to 576 of Muslim immigrants living in France. This research was analyzed using descriptive statistic and multiple regression methods. The result is that positive attitude towards consuming halal meat, relatives with the same religion, and the response for consuming the halal meat affect the Muslims' intention to consume the halal meat.

\section{Theory of Demand}

Demand is the number of products that a household is going to buy in a certain period if the household is able to meet the necessity in accordance with the determined market price (Case and Fair, 2007). Demand is a multivariate connection, which is not determined only by one factor but by many factors at once. Case and Fair (2007) define that the individual's demand on a product and its quantity is affected by several factors including the product price, income and wealth, another product price, expectancy, and taste.

\section{Theory of Consumers' Behavior}

Kotler and Keller (2016) state that the consumers' behavior might be affected by several factors including cultural factors (nation, race, region origin, social class, and religion), social factors (family, friends, and playgroups), and personal factors (ages and lifestyle). 


\section{Method Of Research}

The research population in this study covers all Muslims in Jakarta who have their own income. This research uses non-probability sampling and purposive sampling methods. The determination of the minimal sampling number uses Slovin formula. The formula results in the minimal number of respondents of 100. Contingent Valuation Method is used in the analysis to find out the value the society is willing to pay for the halal-certified meat. Employing a Likert scale, the factor analysis is used to reduce the variables, while the logit regression analysis is used to find out what kind of factors influence WTP for the halal-certified meat.

\section{Contingent Valuation Method}

Contingent valuated method (CVM) is a method used to estimate the economic value of a product unsold in the market and is one of the methods for economic valuation. Hanley and Spash (2013) explain the operational stages of CVM application as follows: (1) building a hypothesis market, (2) getting the bidding value, (3) calculating the WTP average, (4) estimating the WTP bidding curve, and (5) aggregating data.

\section{Factor Analysis}

Factor analysis is a statistic analysis applied to reduce the data or summarize several variables to be the new (construct) variable by still containing the most information in the original variable. Factor analysis identifies the connection structure among the variables or dimensions by seeing the correlation inside them (Ghozali, 2013). Factor analysis in this research is used to summarize the answers of each variable to produce the construct variables that are used in the logistic regression analysis.

\section{Logit Regression Analysis}

This research uses the logit regression analysis method by the STATA 64 application. The binary logit or binary logistic regression model is the quantitative method of the connection between the probability of two choices of some characteristics chosen (Gujarati and Porter, 2009).

The logit basis used in this research is as follows:

$$
W T P=\beta_{1}+\beta_{2} X_{1}+\beta_{3} X_{2}+\beta_{4} X_{3}+\beta_{5} X_{4}+\beta_{6} X_{5}+u_{i}
$$

Where:

WTP : willingness to pay 


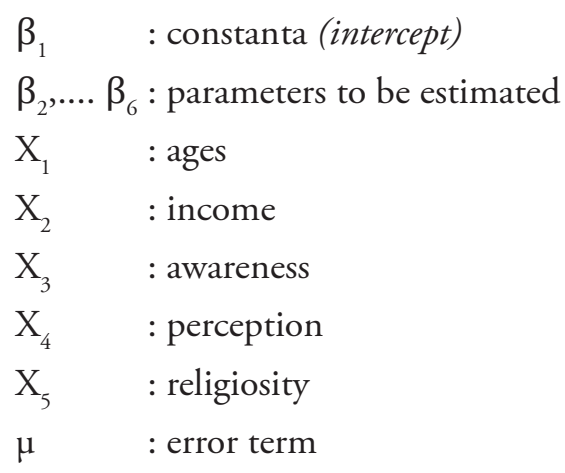

\section{Result And Discussion}

\section{Validity and Reliability Tests}

The validity test indicates that the correlation among each indicator of questions on the total construct score has greater value than 0.5 , so it can be concluded that each indicator of questions is valid in measuring the three variables by using the Likert scale. On the reliability test, it finds the value of Cronbach's Alpha amounted 0.625 (Awareness), 0.877 (Perception), and 0.933 (Religiosity).

Hair et al. (2010) stated that an item with the Cronbach's Alpha value that is greater than 0.6 is reliable, so it can be concluded that all the answers of the questions of a construct using the Likert scale (variables of awareness, perception, and religiosity) are consistent and reliable.

\section{Contingent Valuated Method (CVM)}

The contingent valuated method in this research is used to find out the value of the respondents' willingness to pay for the halal-certified meat. The result of CVM implementation is as follows: 1) building hypothesis market; 2) determining the scale of WTP Bid, and 3) calculating and estimating WTP average value.

The buildings hypothesis market of this research is based on the availability of meat that it's halal status and quality are doubted. This is doubled with the risk of non-halal substance contamination on halal products, which can bring anxiety to Muslim consumers in Indonesia. The government, through LPPOM MUI, has taken action by issuing a halal certificate to the meat products. The halal certificate guarantees that the process of livestock handling has met the Islamic requirement. This certificate is expected to give safety, comfort, and satisfaction for the Muslim consumers, especially for those who consume the meat. 
However, the halal meat certificate raises additional costs in its implementation. The certification requires certain activities and additional equipment in the processing and handling of the meat that meets Islamic law. Consequently, halal-certified beef becomes more expensive.

The above scenario was explained to the respondents as an effort to provide a guarantee to the consumers. The WTP value of halal certified meat will be found out through the questions asked to the respondents, whether the halal certification is needed and whether the respondents are willing to pay a higher value for halalcertified products.

The determination stage of the auction value on the contingent valuation method should use the bidding game, which is the best model and will not raise the bias. However, the depreciation of the auction value with bidding game cannot be conducted due to various obstacles, so that the auction value bid will be conducted by the payment cards method. This method uses the payment card application with several bidding ranges provided. The respondents will answer by choosing the range of expense they are willing to pay for getting the halal-certified meat. The bidding range available is selected from research taken by Tieman et al. (2013) that is $0-5 \%$, 5-10\%, 15-20\%, and 20-25\%.

Calculating the estimation of WTP's average value of this research used an alternative estimation method. The alternative estimation method applied for the interval data is interval midpoint WTP model provided by Hackl and Pruckner (1999). This method assumes that the individual WTP value distributed into the existing interval is among the selected value with the greater next value. Shen (2012) assumes the midpoint of the existing as a WTP value. The distribution data of respondents' WTP is shown in Table 1.

Table 1. Distribution of WTP Value of Respondents Willing to Pay

\begin{tabular}{ccccc}
\hline No & Bid Range & Midpoint & Number of Respondents & Percentage \\
\hline 1 & $0-5 \%$ & 2.5 & 53 & 0.69 \\
2 & $5-10 \%$ & 7.5 & 17 & 0.22 \\
3 & $10-15 \%$ & 12.5 & 6 & 0.08 \\
4 & $15-20 \%$ & 17.5 & 1 & 0.01 \\
5 & $20-25 \%$ & 22.5 & 0 & 0 \\
& Total & & 79 & 1.00 \\
\hline
\end{tabular}

Source: primary data, processed in 2017. 
The WTP average value is acquired by using the following formula:

$E W T P=\sum_{i=0}^{H-1} \frac{A_{i}+A_{i+1}}{2} P_{i}+\frac{A_{H}+A_{T}}{2} P_{H}$

Where $A_{i}$ is the chosen WTP value, $A_{i+1}$ is the next greater WTP value, $P_{i}$ is the percentage of the respondents choosing the I WTP value, $A_{H}$ is the highest dealing value, $A_{T}$ is the top limited value, and $P_{H}$ is the percentage of the respondents choosing the greatest WTP value. The WTP average that is willing to be paid by the consumers to get the halal-certified beef is $7.05 \%$ over the regular beef price.

\section{Factor Analysis}

The main object of this method is to reduce the great data into one set of dimension by identifying how far each variable can be explained by each dimension. The factor analysis in this research is used to summarize 28 questions for the variables using the Likert scale (X3, X4 and X6) to produce the score of the variable factor.

Table 2. Variables of Factor Analysis Result

\begin{tabular}{llc}
\hline & Variables & Code \\
\hline Awareness & Awareness of halal aspects & X3_1 \\
& Awareness of MUI label & X3_2 \\
Perception & Perception on halal meat ceritificate & X4 \\
Religiosity & Religiosity of belief and shall worship dimensions & X5_1 \\
& Religiosity of sunnah worship and hablumminannas dimensions & X5_2 \\
\hline
\end{tabular}

Source: primary data, processed 2017

\section{Logit Regression Analysis}

The logit regression analysis is the regression analysis used in the research using the data with the binary dependent variables ( 0 and 1$)$. In this research, value 1 is given to the consumers who are willing to pay more for the halal-certified beef. Value 0 is given to the respondents who are not willing to pay more to the halalcertified beef product.

The testing is conducted to find out the influence of ages, income, awareness, perception, and religiosity on the willingness to pay more for the halal-certified beef. The estimation result of logit regression of the consumers' willingness to pay is conducted by the STATA 64 software and shown in Table 3. 
Table 3. Regression Result of Public Willingness to Pay

\begin{tabular}{ccccc}
\hline Variables & Coefisien & dy/dx & Statistic z & Probability z \\
\hline X1 & -0.00293 & -0.00036 & -0.14 & 0.889 \\
X2 & 0.35048 & 0.43640 & 0.57 & 0.572 \\
X3_1 & 0.52630 & 0.65531 & 1.24 & 0.241 \\
X3_2 & 1.36655 & 0.17015 & 3.71 & $0.000^{*}$ \\
X4 & 0.74361 & 0.09259 & 1.86 & $0.063^{* *}$ \\
X5_1 & 0.39533 & 0.04922 & 1.05 & 0.294 \\
X5_2 & -0.01067 & 0.00132 & -0.03 & 0.976 \\
Constanta & -3.60682 & & -0.37 & 0.708 \\
\hline
\end{tabular}

The logit regression result finds that the value of statistic Hosmer-Lemeshow amounted 6.77 and has the probability value of chi-square amounted $0.56>$ 0.05 , so $\mathrm{H}_{0}$ is accepted, and the model is stated to be fit. Meanwhile, McFadden R-Squared has the value of 0.342 , which means that the dependent variable can only be explained by the independent variable amounted 34\%, and the rest is explained by other factors outside the model. The testing result indicates that the LR statistic has the value of 37.72 with the probability of $0.000<0.5$, so it can be concluded that the independent variables jointly or simultaneously affect the dependent ones.

Table 3 indicates that from 7 independent variables tested there is one variable that significantly affects the dependent variables on 5\% level that is variable of Awareness on MUI label (X3_2) and variable of perception (X4) that is significant on $10 \%$ level while the other variables do not significantly affect the dependent ones because they have the probability values of z-statistic greater than 0.05 and 0.1 .

\section{Effect of Income on WTP}

The logit regression result indicates that the variable of income has the opportunity coefficient value amounted 0.043 with the probability of $0.57>0.05$. So it can be concluded that the variable of income (X2) has no significant effect on WTP for the halal-certified beef. The opportunity coefficient of the variable of income (X2) indicates the positive sign amounted 0.043 , which means that people with higher income will increase the probability of their willingness to pay for the halal-certified beef amounted $4.3 \%$.

The result is not in accordance with the hypothesis in which the income 
is considered to affect the willingness to pay significantly. This indicates that the income level is not the main factor affecting public willingness to pay for the halalcertified beef. The higher ability of purchasing power does not guarantee the people to be willing to pay more.

\section{Effect of Ages on WTP}

The variable of ages has the opportunity coefficient amounted -0.00036 with the probability value of 0.889 . On the significance level of $5 \%(0.05)$, it can be concluded that the variable of ages has no significant effect on the WTP for halal-certified beef. The result found is in accordance with the research conducted by Ibrahim (2011) and Kamaruddin et al. (2012), which found that ages do not significantly affect public willingness to pay. This indicates that public WTO for the halal-certified meat cannot be predicted through someone's experience, knowledge or belief that is formed during his/her whole period of life.

The opportunity coefficient of the age variable (X1) amounted -0.00036 indicates that people with older ages will reduce the probability of willingness to pay more for the halal-certified beef amounted $0.03 \%$. The connection explains that the respondents with younger ages have more opportunity to be willing to pay more rather than the older respondents.

The result is in accordance with the research of Verbeke et al. (2013), which stated that the halal label on the meat product is important for the younger generation, but not for the older one. This is because the younger one has little trust in the halal product by only seeing the status and background of the seller. They demand that the labelling should be under a trusted organization to guarantee the halal status of the product.

\section{Effect of Awareness on WTP}

The variable of awareness on the importance of halal labelling affects the willingness to pay for the halal-certified beef (X3_1) with the opportunity coefficient amounted 0.06 . The probability value found is 0.214 , that is fewer than the alpha level of $5 \%$. The opportunity coefficient of the variable of awareness (X3_1) indicates the positive sign of 0.65 , which means that people with higher awareness of the importance of halal labelling will increase the probability of willingness to pay for the halal-certified beef amounted 6.5\%.

The awareness variable is the halal label of MUI (X3_2) having opportunity coefficient value of 0.1701 and probability $Z$ equal to 0.000 . It can be concluded that there is a significant influence of the awareness of halal label MUI on certified 
halal certified beef. The opportunity coefficient of MUI halal label awareness variable (X3_1) indicates a positive sign of 0.1701 . It means that people with higher levels of MUI label awareness will increase their probability of willing to pay for the halal-certified meat of $17.01 \%$.

The result is in accordance with the research of Putri et al. (2016), which stated that public awareness level has a significant effect on the willingness to pay for the halal-certified product. The more someone is aware of the halal concept in various consumption activities, the greater the probability the person to be willing to pay more for getting a product with a halal guarantee. The halal certificate on the meat products is considered important enough to keep the product condition from the manipulation and contamination of non-halal substances, so people are willing to pay more for the service existence.

\section{Effect of Perception on WTP}

The variable of perception has the opportunity coefficient value of 0.092 with the probability z of 0.06 , which means that the variable of perception does not significantly affect the WTP for the halal-certified beef. The opportunity coefficient of the variable of perception (X4) is positive of 0.092 , which means that people who think that the halal-certified meat is important will have a greater probability to be willing to pay for the halal-certified meat amounted $9.2 \%$.

The result is in accordance with the research of Fathi, et al. (2016), which found the consumers' perception on the halal logistics has a positive correlation with the willingness to pay for the halal logistics.

\section{Effect of Religiosity on WTP}

The variable of religiosity based on the belief and will-worship shows the opportunity coefficient value of 0.049 with the probability $z$ of 0.292 . It indicates that this type of religiosity variable has no significant effect on the willingness to pay for the halal-certified beef. The opportunity coefficient (X5_1) is positive of 0.049, which means that people with the higher level of religiosity based on belief and willworship will have a greater probability to be willing to pay for the halal-certified beef amounted $4.9 \%$.

The variable of religiosity based on the sunnah rituals and hablumminannas or relationship with other humans has the opportunity coefficient value of -0.0013 and the probability $\mathrm{z}$ of 0.976 , which means that this kind of religiosity variable has no significant effect on the WTP for the halal-certified beef. The opportunity coefficient of -0.0013 indicates that people with the higher level of religiosity based 
on the sunnah rituals and good relationship with other humans have a greater probability of being not willing to pay for the halal-certified beef amounted $0.13 \%$.

The result is in accordance with the research of Astogini et al. (2011), which explained that the religious aspect has no significant effect on the decision of buying the halal products. This may because the religious aspects like belief, rituals, and consequence are an obligation for a Muslim, apart from his/her consumption activities. So, both factors have no connection with Muslims' decision to use halalcertified products/services.

\section{Conclusion}

The existence of the halal-certified meat is considered important as an effort to avoid the manipulation and contamination of haram substance on the halal meat product. Of 100 respondents, 77 are willing to pay more while the rest (23) are not. Of the willing respondents, 53 are willing to pay for the halal-certified beef amounted $0-5 \%$, and the rest are willing to pay for more than $5 \%$ of the prevailing meat price.

Based on the interview results using the contingent valuated method, the average value of the Muslims in Jakarta who have the willingness to pay for the halal-certified beef is $7.05 \%$ over the prevailing beef price. The value is acquired by using the interval midpoint method.

The logit regression analysis using the factor variable finds that only the variable of awareness that affects the Muslims in Jakarta to have the willingness to pay for the halal-certified beef, while the variables of income, ages, perception, and religiosity have no significant effects on public willingness to pay for the halalcertified beef.

\section{Limitation}

This research does not use the bidding game method in estimating public WTP for the halal-certified meat. This research was only conducted in Jakarta Province and only used the level of $10 \%$ in determining the sample. Therefore, the space of this research is very narrow to find out better responds to halal-certified meat.

\section{Suggestion}

Further research is expected to use the bidding game method to find better out the amount of cost of public willingness to pay for the halal-certified beef. 
Research with greater sample and wider space area is expected to be conducted in the future. The further research is also expected to be able to investigate the halal process topics such as halal supply chain and halal logistics, considering that halal process has a very close relationship with various activities in the supply chain.

\section{References}

Angulo, A. M., \& Gil, J. M. 2007. "Risk Perception and Consumer Willingness to Pay for Certified Beef in Spain." Food Quality and Preference 18(8): 1106-1117. Anon. (2004). Al-Qur'an dan Terjemahnya. Bandung: J-Art.

Astogini, Dwiwiyati, Wahyudin, \& Siti Zulaikha Wulandari. 2011. Aspek Religiusitas dalam Keputusan Pembelian Produk Halal. Jeba 13(1): 1-8.

Bonne, Karijn \& Wim Verbeke. 2006. "Muslim Consumer Attitude towards Meat Consumption in Belgium." Anthropology of Food 5: 1-24.

Bonne, Karijn, Iris Vermer \& Wim Verbeke. 2008. "Impact of Religion on Halal Meat Consumption Decision Making in Belgium." Journal of International Food \& Agribusiness Marketing 21(1): 5-26.

Case, Karl E \& Ray C. Fair. 2007. Principles of Economics. $8^{\text {th }}$ ed. New Jersey: Pearson Education.

Fathi, Elahe, Suhaiza Zailani, Mohammad Iranmanesh \& Kanagi Kanapathy. 2016. "Drivers of Consumers' Willingness to Pay for Halal Logistics." British Food Journal 118(2): 464-479.

Fauzi, Akhmad. 2004. Ekonomi Sumber Daya Alam dan Lingkungan: Teori dan APlikasi. Jakarta: Gramedia Pustaka Utama.

Ghozali, I. 2013. Aplikasi Analisis Multivariate dengan Program SPSS IBM21. Semarang: Badan Penerbit Universitas Diponegoro.

Gujarati, Damodar N., \& Dawn C. Porter. 2009. Basic Econometrics. $5^{\text {th }}$ ed. New York: McGraw-Hill.

Hair, Joseph F, William C. Black, Barry J. Babin and Rolph E. Anderson. 2010. Multivariate Data Analysis. $7^{\text {th }}$ ed. Upper Saddle River, NJ: Prentice Hall.

Hanley, Nick \& Clive L Spash. 2013. Cost-Benefit Analysis and The Environment. England: Edward Elgar Publishing Limited.

Ibrahim, M. 2011. "Consumer Willingness to Pay a Premium for Halal Goat Meat: A Case from Atlanta, Georgia." Food Distribution Research 42(1): 72-76.

Kamaruddin, R., Iberahim, H., \& Shabudin, A. 2013. "Factors Influencing Customers Willingness to Pay for Halal Logistics." ASIAN Behavioural Studies 3(9): 41-52. 
Kompas. (2017). Petugas Gagalkan Penyelundupan 310 Daging Gelonggongan diGrobogan. http://regional. kompas. com/read /2017/06/16/11110051/.

Kotler, Philip, and Kevin Lane Keller. 2016. Marketing Management. $15^{\text {th }}$ ed. USA: Pearson Education.

Mankiw, N. Gregory. 2013. Principles of Microeconomics. $7^{\text {th }}$ ed. United States of America: Cengage Learning.

Priambodo, Luthfan Hadi. 2013. Analisis Kesediaan Membayar Sayuran Organik dan Faktor-Faktor yang Mempengaruhinya. Bogor: Institut Pertanian Bogor.

Putri, Wilda Rizkilia, Muh Samsudin, Edy Rianto \& Indah Susilowati. 2015. "Consumers' Willingness to Pay for Halal Labelled Chicken Meat: A Special Reference to Pedurungan Sub District, Semarang City." Jurnal Dinamika Manajement 8(1): 122-133.

Tieman, Marco, Maznah Che Ghazali \& Jack G.A. J. van der Vorst. 2013. "Consumer Perception of Halal Meat Logistics." British Food Journal 115(8): 1112-1129.

Tieman, Marco \& Maznah Che Ghazali. 2014. "Halal Control Activities and Assurance Activities in Halal Food Logistics." Procedia - Social and Behavioral Sciences 121(September 2012): 44-57.

Verbeke, Wim. 2005. "Agriculture and The Food Industry in The Information Age." European Review of Agricultural Economics 32: 347-368.

Verbeke, Wim, Peter Rutsaert, Karijn Bonne \& Iris Vermeir. 2013. "Credence Quality Coordination and Consumers' Willingness-to-Pay for Certified Halal Labelled Meat." Meat Science 95(4): 790-797.

Zakaria, Zalina. 2008. "Tapping into The World Halal Market: Some Discussions on Malaysian Laws and Standards." Shariah Journal, 16: 603-613. 